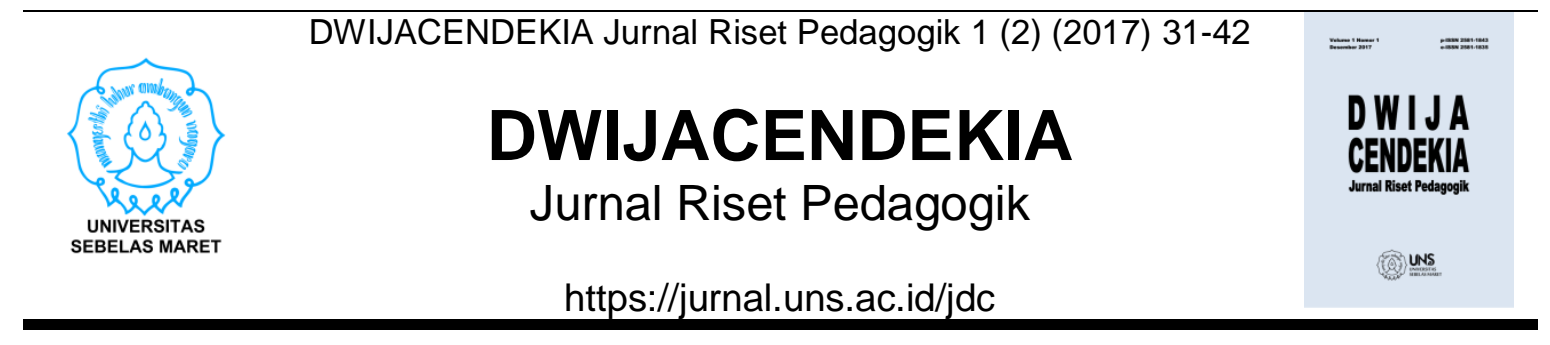

\title{
PENGEMBANGAN BAHAN AJAR FLASH BOOK SEJARAH PERADABAN INDONESIA UNTUK MENINGKATKAN HASIL BELAJAR SISWA KELAS V SD
}

\author{
Hatma Heris Mahendra \\ Universitas Perjuangan Tasikmalaya
}

\section{Sejarah Artikel}

Diterima 18 September 2017

Disetujui 6 Oktober 2017

Diterbitkan 1 Desember 2017

\section{Kata Kunci}

Bahan ajar, flash book, hasil belajar

\begin{abstract}
Abstrak
Penelitian ini bertujuan untuk mendeskripsikan kelayakan dan kefektivitas bahan ajar flash book sejarah peradaban Indonesia yang telah dikembangkan. Penelitian ini merupakan jenis penelitian pengembangan dengan desain penelitian 4-D. Penilaian kelayakan pada hasil pengembangan bahan ajar flash book dilaksanakan oleh validator ahli materi dan validato ahli media. Pengujian hipotesis dilakukan dengan menggunakan tes tulis berupa pre test dan post test. Data hasil penelitian yang diperoleh sebagai berikut penilaian dari validator ahli materi yang menunjukkan presentase hasil penilaian sebesar $93,75 \%$ yang tergolong sangat baik dan penilaian dari validator ahli media yang menunjukkan presentase sebesar $91,67 \%$ yang tergolong sangat baik. Berdasarkan penilaian dari validator ahli tersebut bahan ajar flash book yang dikembangkan dinyatakan layak. Sedangkan untuk pengujian hipotesis yang dianalisa dengan $u j i ~ t$ menunjukkan bahwa hasil belajar siswa pada kelas eksperimen lebih tinggi dibandingkan hasil belajar siswa pada kelas kontrol. Hal ini ditunjukkan dengan nilai thitung (3.979) > tabel (1.673). Jadi, penggunaan bahan ajar flash book berpengaruh terhadap hasil belajar siswa.Berdasarkan hasil analisis data, dapat disimpulkan bahwa bahan ajar flash book sejarah peradaban Indonesia layak dan efektif meningkatkan hasil belajar siswa kelas $\mathrm{V}$ sekolah dasar.
\end{abstract}

Cara Mengutip

Mahendra, H.H. (2017). Pengembangan Bahan Ajar Flash Book Sejarah Peradaban Indonesia Meningkatkan Hasil Belajar Siswa Kelas V SD. DWIJACENDEKIA Jurnal Riset Pedagogik, 1(2), 31-42.
Korespondensi Penulis: hatma.mahendra@gmail.com
p-ISSN 2581-1843

e-ISSN 2581-1835 


\section{PENDAHULUAN}

Pendidikan adalah upaya sadar manusia untuk memanusiakan manusia. Pendidikan juga menyiapkan anak untuk kehidupan dimasa yang akan datang dan pendidikan juga merupakan upaya untuk mencapai kedewasaan. Pendidikan merupakan faktor yang sangat mempengaruhi perkembangan anak dimasa datang. Perkembangan yang dimaksud adalah perkembangan dalam aspek kognitif, aspek psikomotor, dan aspek afektif. Didalam kegiatan belajar - mengajar kegiatan belajar merupakan kegiatan utama, sedangkan kegiatan mengajar merupakan kegiatan untuk mengoptimalkan kegiatan belajar.

Inti pendidikan sesungguhnya berada pada proses pendidikan atau proses pembelajaran. Menurut Slameto (2010: 2) belajar ialah suatu proses yang dilakukan seseorang untuk memperoleh suatu perubahan tingkah laku yang baru secara keseluruhan, sebagai hasil pengalamannya sendiri dalam interaksi dengan lingkungannya. Setelah proses pembelajaran diharapkan siswa dapat mengalami peningkatan dalam aspek kognitif yang berhubungan dengan kemampuan siswa memahami pelajaran, aspek psikomotor yang berhubungan dengan katerampilan, serta aspek afektif yang berhubungan dengan sikap siswa.

Agar mencapai hasil pembelajaran yang diharapkan maka dalam pembelajaran diharapkan adanya interaksi antara siswa dengan guru yang berjalan dua arah. Guru tidak hanya menyampaikan materi pelajaran saja, tetapi juga terjadi interaksi dengan siswa. Peran guru sangat sentral dalam kegiatan pembelajaran. Guru tidak hanya berperan sebagai pengajar, tetapi guru juga berperan sebagai pembimbing, pemberi fasilitas, dan temapt siswa untuk mengungkapkan kesulitan yang dialaminya. Dalam pemblajaran guru dapat menggunakan media atau bahan ajar dengan basis teknolog baru.

Upaya meningkatkan kualitas proses pembelajaran maka pada tahun 2013 pemerintah memperkenalkan kurikulum 2013 yang menggantikan kurikulum sebelumnya yaitu kurikulum tingkat satuan pendidikan atau biasa disebut KTSP. Dalam kurikulum 2013 pembelajaran tidak dibagi berdasarkan mata pelajaran akan tetapi dikelompokkan dalam tema tertentu. Berdasarkan kurikulum 2013 pada pembelajaran di kelas $\mathrm{V}$ sekolah dasar dibagi menjadi Sembilan tema dan setiap tema akan dibagi menjadi beberapa sub tema.

Dalam prakteknya kurikulum 2013 menggunakan buku guru sebagai pedoman guru dalam menyampaikan materi kepada siswa sertabuku siswa sebagai bahan belajar siswa. Kenyataan yang didapati di lapangan buku siswa yang semestinya menjadi bahan belajar bagi siswa masih memliki beberapa kekurangan antara lain kurangnya materi dalam buku siswa sehingga banyak siswa yang mengalami kesulitan dalam belajar karena harus mencari bahan belajar lain. Hal ini dapat berpengaruh pada 
hasil belajar siswa khususnya dalam aspek kognitif.

Salah satu upaya untuk meningkatkan hasil belajar siswa yaitu dengan dikembangkannya bahan ajar flash book yang berbasis teknologi untuk menyesuaikan proses pembelajaran dengan perkembangan teknologi di era digital ini. Dengan dikembangkanya bahan ajar flash book ini diharapkan dapat membantu siswa dalam proses belajar mengajar serta membantu siswa dalam mempelajari materi pelajaran yang akan meningkatkan hasil belajar siswa. Hal tersebut dikarenakan dalam bahan ajar flash book tidak hanya terdiri dari teks dan gambar saja melainkan dapat juga diberikan contoh berupa video maupun audio. Selain itu bahan ajar flash book dapat dipelajari dimana saja tanpa membawa buku fisik melainkan dapat dipergunakan melalui alat seperti smartphone, laptop, maupun computer serta tablet. Dalam penggunaannya di kelas guru dapat menampilkan melalui bantuan proyektor. Selain hal tersebut dengan diterapkannya bahan ajar berbasis digital akan membantu dalam pelestarian lingkungan karena tidak perlunya penggunan kertas dalam pengemasan bahan ajar. Menurut Tanner (2014) kemajuan dalam teknologi digital akan terus meningkatkan kenyamanan dan kemudahan dengan adanya buku elektronik yang dapat didownload di smartphone utatau komper karena keunggulan tampilan, ketersediaan kognitif, atau kesesuaian metakognitif, platform ini tampaknya unggul dari paltform yang lain, itu dapat diasumsikan bahwa itu akan mendominasi pasar buku di masa depan.
Berdasarkan uraian latar belakang tersebut maka peneliti akan mengkaji melalui penelitian pengembangan dengan judul "Pengembangan Bahan Ajar Flash Book Sejarah Peradaban Indonesia untuk Meningkatkan Hasil Belajar Siswa Kelas V Sekolah Dasar". Tujuan dari penelitian ini sebagai berikut: (1) Mendeskripsikan kelayakan hasil pengembangan bahan ajar flash book sejarah peradaban Indonesia (2) Mendeskripsikan efektivitas bahan ajar flash book sejarah peradaban Indonesia dalam dalam meningkatkan hasil belajar siswa kelas $\mathrm{V}$ sekolah dasar

Menurut National Center for Vocational Education Research Ltd, dalam Prastowo (2014: 138) bahan ajar adalah segala bentuk bahan yang digunakan untuk membantu guru atau instruktur dalam melaksanakan proses pembelajaran di kelas. Bahan yang dimaksud bisa berupa bahan tertulis dan tak tertulis. Bahan ajar merupakan separangkat materi yang disusun secara sistematis, baik tertulis maupun tidak, sehingga tercipta lingkungan atau suasana yang memungkinkan peserta didik untuk belajar. Adapula yang berpendapat bahwa bahan ajar adalah informasi, alat, dan teks yang diperlukan guru atau instruktur untuk perencanaan dan penelahaan implementasi pembelajaran. Pandangan ini dilengkapi oleh Pannen bahwa bahan ajar atau bahan atau materi pelajaran yang disusun secara sistematis yang digunakan guru dan peserta didik dalam proses pembelajaran.

Menurut Muslich (2010:133) sebelum menulis bahan ajar harus memahami landasan penulisan bahan ajar yaitu: 
(1) Landasan Keilmuan Ini berarti bahwa setiap penulis buku teks harus memahami dan menguasai teori yang terkait dengan bidang keilmuan atau bidang keilmuan atau bidang studi yang ditulisnya. Dengan demikian penulis buku teks biologi harus memahami dan menguasai teori yang terkait dalam bidang studi biologi. Begitu juga, penulis buku teks kimia, fisika, matematika, sosiologi, sejarah, bahasa indonesia dan pendidikan agama harus memahami dan menguasai teori yang terkait dengan bidang studi yang ditulisnya. Secara teknis landasan keilmuan ini meliputi aspek keakuratan materi, aspek cakupan materi, aspek pendukung materi (2) Landasan IImu Pendidikan dan Keguruan, landasan kedua yang perlu diperhatikan dalam penulisan buku tks adalah landasan pendidikan dan keguruan, terutama hal-hal yang terkait dengan hakikat belajar, pembelajaran konstektual, pembelajaran model pakem, dan pengembangan ativitas, kreativitas, dan motivasi siswa. (3) Landasan Kebutuhan Siswa, landasan ketiga yang perlu diperhatikan dalam penulisa buku teks adalah landasan kebutuhan siswa. Hal itu dikarenakan landasan kebutuhan ini erat kaitannya dengan motivasi, maka pemahaman tantang teori motivasi perlu diperdalam.Motivasi dapat diartikan sebagai kekuatan (energi) seseorang yang dapat menimbulkan tingkat persistensi dan anusianismenya dalam melaksanakan suatu kegiatan, baik yang bersumber dari dalam diri individu (motivasi intrinsik) maupun dari luar individu (motivasi ekstrinsik). Seberapa kuat motivasi yag dimiliki individu akan banyak menentukan terhadap kualitas perilaku yang ditampilkannya, baik dalam konteks belajar, bekerja, maupun dalam kehidupan lainnya. (4) Landasan Keterbacaan Materi dan Bahasa Yang Digunakan, Landasan keempat yang perlu diperhatikan dalam penulisan buku teks adalah landasan keerbacaan materi dan bahasa yang digunakan. Landasan ini diperlukan karena buku teks merupakan sarana komunikasi siswa dalam pembelajaran. Sebagai sarana komunikasi, materi dan redaksi sajian yang terdapat dalam buku teks harus bisa dipahami siswa. Secara teknis, indikator yang digunakan dalam buku teks adalah komunikatif, dialogis dan interakti, lugas keruntutan alur pikir, koherensi, kesesuaian dengan kaidah bahasa Indonesia yang benar dan penggunaan istilah dan simbol atau lambang yang sesuai dengan perkembangan peserta didik.

Flash book adalah buku digital dengan format flash yang dapat berisikan content berupa teks, gambar,animasi, audio serta audio visual yang dibuat dengan menggunakan aplikasi Macromedia Flash. Menurut Kumolo (2005:1) Macromedia Flash merupakan program yang dibuat oleh perusahaan macromedia untuk keperluan pembuatan aplikasi dan animasi web interaktif. Program ini dirancang untuk animasi berbasis vector sehingga sehingga menghasilkan file ukuran kecil juga merupakan program yag didesain dengan kemampuan untuk membuat 2 animasi dimensi yang handal dan ringan sehingga macromedia flash banyak digunakan untuk membangun dan memberikan efek animasi pada website, CD interaktif dan yang lainnya. Menurut Yudhiantoro (2003:3) Macromedia Flash adalah sebuah program animasi yang telah banyak digunakan oleh animator untuk menghasilkan animasi 
yang professional. Animasi adalah gambar mati (grafis statis) yang dibuat efek sehingga seoah-olah tampak bergerak. Clark, dkk(1991:210) menyatakan semua informasi diproses melalui dual chanel yang independen yaitu chanel verbal seperti teks, dan suara dan chanel visual seperti diagram, animasi dan gambar. Berdasarkan dari pengertian tersebut dapat disimpulkan bahwa, animasi merupakn suatu kegiatan menghidupkan, mengerakkan, benda mati. Suatu benda mati diberi dorongan, kekuatan, semangat dan emosi untuk menjadi hidup atau hanya berkesan hidup.

Buku teks dengan basis elektronik (eBuku teks) atau buku digital adalah bentuk digital dari buku teks pelajaran yang berpotensi akan menggantikan buku pelajaran berbasis kertas yang ada dalam kurikulum sekolah. Menurut Yau dkk (2013:32) Dibandingkan dengan buku teks tradisional, keuntungan dari buku elektronik yang pertama ada penggabungan isi multimedia, seperti klip video, animasi dan game berbasis pendidikan, adalah beberapa unsur Buku Pelajaran elektronik yang telah terbukti dapat meningkatkan minat siswa dalam belajar. Kedua, Buku teks elektronik memungkinkan guru untuk "menyesuaikan dan menghasilkan konten dengan pemaknaan ulang sesuai apa yang perlu diajarkan, menggunakan modul yang berbeda yang mungkin sesuai dengan gaya belajar siswa, wilayah, bahasa, atau tingkat keterampilan, yang berpegang pada standar pendidikan. Berikutnya bagian buku pelajaran generasi terbaru ini memungkinkan siswa agar tidak lagi membawa ransel penuh dengan buku teks berat untuk sekolah. Kemudian, Buku Pelajaran elektronik memungkinkan backup mudah dan penggantian sehingga kerugian dapat dengan mudah digantikan oleh salinan baru dari server atau perangkat penyimpanan lain. Kelima, pembaruan cepat dan akses ke konten terbaru yang mungkin.

\section{METODOLOGI}

Penelitian ini termasuk dalam jenis penelitian pengembangan yang mempunyai tujuan untuk mengembangkan perangkat pembelajaran bahan ajar dalam bentuk buku ajar. Bahan ajar yang dikembangkan dalam penelitian ini adalah bahan ajar untuk tema sejarah peradaban Indonesia. Menurut Sugiyono (2011:407) penelitan pengembangan adalah metode penelitian yang digunakan untuk menghasilkan produk tertentu, dan menguji kefektifan produk tersebut.

Model yang digunakan dalam pengembangan bahan ajar ini adalah model Thiagarajan 4-D (Four $D$ Model). Model pengembangan yang dikemukakan Thiagarajan, Semmel dan Semmel yang biasa disebut Four $D$ Model (model 4-D terdiri atas (1) Pendefinisian (defne), meliputi analisis awal, analisis siswa, analisis konsep, analisis tugas dan perumusan tujuan pembelajaran; (2) Perancangan (design) meliputi penyusunan perangkat pembelajaran, pemilihan media, pemilihan format, dan desain awal; (3) Pengembangan (develop), meliputi validasi ahli dan uji coba; dan (4) Penyebaran (dissemite). 
Penelitian dilakukan di SDN Medokan Ayu I/270 yang bertempat di Jl. Medokan Ayu No. 7 Kel. Medokan Ayu Kec. Rungkut Surbaya.Subjek dari penelitian ini adalah bahan ajar Flash book yang didesain dengan basis multimedia yang diimplementasikan pembelajaran tema sejarah peradaban Indonesia. Sedangkan objek uji coba pada penelitian ini adalah siswa-siswi kelas $\mathrm{V} A$ dan $\mathrm{V} B$ SDN Medokan Ayu 1/270 Surabaya. Dimana pada kelas $V$ A berjumlah 29 siswa dan IV B berjumah 27 siswa pada tahun pelajaran 2015/2016. Dengan sampel terdiri dari dua kelas, dimana satu kelas sebagai kelas eksperimen dan satu kelas lagi sebagai kelas control. Untuk kelas control dilakukan pada kelas $\mathrm{V} A$ sedangkan untuk kelas eksperimen menggunakan kelas $\mathrm{V} B$.

Rancangan penelitian uji coba di lapangan bahan ajar flash book yang menggunakan rancangan randomized control-group pretest-posttest design yang dikembangkan oleh Suryabrata (2011:203).Pada rancangan ini diberikan tes awal dan tes akhir pada kelas eksperimen maupun kelas control. Kelompok eksperimen adalah kelompok yang diberikan perlakuan dengan menggunakan bahan ajar flash book pada proses belajar menggajarnya, sedangkan pada kelas control tidak menggunakan media pembelajaran. Rancangan penelitian ini disajikan

Tabel 1. Rancangan Penelitian

\begin{tabular}{|c|c|c|c|c|}
\hline \multirow{2}{*}{$\mathrm{R}$} & Kelompok & $\begin{array}{c}\text { Tes } \\
\text { Awal }\end{array}$ & Perlakuan & $\begin{array}{c}\text { Tes } \\
\text { Akhir }\end{array}$ \\
\cline { 2 - 5 } & Eksperimen & $\mathrm{T}_{1}$ & $\mathrm{X}$ & $\mathrm{T}_{2}$ \\
\cline { 2 - 5 } & Kontrol & $\mathrm{T}_{1}$ & - & $\mathrm{T}_{2}$ \\
\hline
\end{tabular}

Keterangan:

$\mathrm{R}=$ Kelompok eksperimen dan kelompok kontrol dipilih secara random.

$\mathrm{T}_{1}=\mathrm{Uji}$ awal (pretest), untuk mengetahui penguasaan awal siswa terhadap pengetahuan tentang materi sebelum diberikan perlakuan.

$\mathrm{T}_{2}=$ Uji akhir (posttest), untuk mengetahui penguasaan siswa terhadap pengetahuan tentang materi.

$\mathrm{X}=$ Perlakuan yaitu pelaksanaan pembelajaran dengan menggunakan bahan ajar flash book.

Untuk menganalisis data dalam proses pengembangan bahan ajar flash book yang merupakan pengamatan dari validator, dianalisis dengan rumus koefisien kesepakatan sebagai berikut:

PSA
$=\frac{\sum \text { Alternatif jawaban terpilih setiap aspek }}{\sum \text { Alternatif jawaban ideal setiap aspek }} \times 100 \%$

(Riduwan, 2011:21)

Adapun kreteria penilaian dalam mengevaluasi ini adalah :

100-81= Sangat Baik

80-61= Baik

$60-41=$ Kurang Baik

40-21= Tidak Baik

$20-0=$ Sangat Tidak Baik

(Riduwan, 2011:21)

Analisis Aktivitas Siswa dan Guru Pengamatan terhadap kegiatan pembelajaran dilakukan oleh dua orang pengamat. Data penilaian pelaksanaan kegiatan pembelajaran dianalisis berdasarkan rata-rata skor pelaksanaan pembelajaran yang dilakukan peneliti. Data hasil pengamatan keaktifan siswa, selama KBM berlangsung dianalisis dengan menggunakan rumus sebagai berikut. 


$$
\mathrm{P}=\frac{\mathrm{f}}{\mathrm{N}} \times 100 \%
$$

Kategori :

$\mathrm{P} \quad=$ Persentase

$\mathrm{f}=$ Banyak keaktifan yang terlaksana

$\mathrm{N} \quad=$ Jumlah keseluruhan keaktifan yang dinilai

(Winarsunu, 2009:20)

Uji normalitas penting diketahui berkaitan dengan ketetapan pemilihan uji statistik yang akan digunakan. Uji normalitas digunakan untuk mengetahui normal tidaknya sebaran yang digunakan dalam penelitian ini. Uji normalitas penelitian ini dilakukan dengan menghitung antara nilai pretest dengan nilai pretest antara kedua kelompok dan nilai posttest dengan nilai posttest antara kedua kelompok pula. Uji normalitas yang digunakan adalah uji Chi Square dengan hipotesis:

$$
X^{2}=\Sigma\left\lceil\frac{(f o-f e)^{2}}{f e}\right\rceil
$$

Keterangan:

$\mathrm{x}^{2}=$ nilai chi square

fo $=$ frekuensi yang diperoleh

$f e=$ frekuensi yang diharapkan

(Winarsunu,2009:88)

Pengujian homogenitas dilakukan untuk menguji kesamaan dari beberapa bagian sampel. Uji homogenitas dilakukan dengan menghitung antara nilai pretest dengan nilai pretest antara kedua kelompok dan nilai posttest dengan nilai posttest antatra kedua kelompok pula. Prosedur yang digunakan peneliti adalah uji $\mathrm{F}$ dengan kriteria sebagai berikut.

$$
\text { Fmax }=\frac{\text { Var. Tertinggi }}{\text { Var. Terendah }}
$$

Adapun kriteria pengujian digunakan pada taraf signifikansi 5\% $(0,05)$. Dalam hal ini hipotesis yang diuji adalah:

Ho = varians pada tiap kelompok sama (homogen)

$\mathrm{H}_{1}=$ varians pada tiap kelompok tidak sama (tidak homogen)

Hipotesis didefinisikan sebagai jawaban sementara terhadap rumusan masalah penelitian. Setelah melakukan uji normalitas dan uji homogenitas, maka langkah selanjutnya adalah menguji hipotesis.

Untuk mengukur tingkat pemahaman siswa sebelum mengikuti pembelajaran subtema kerajaan Islam di Indonesia dengan pengembangan bahan ajar flash book dan sesudahnya digunakan teknik analisi data uji t dua sampel bebas dengan Tumus separated varian adalah sebagai berikut:

$$
t=\frac{X_{1}-X_{2}}{\sqrt{\frac{S_{1}^{2}}{n_{1}}}+\sqrt{\frac{S_{2}^{2}}{n_{2}}}}
$$

Keterangan :

(Sugiyono, 2011:273)

$$
\begin{array}{ll}
\mathrm{t} & =\text { nilai t hitung } \\
\mathrm{X}_{1} & =\text { nilai rata-rata kelompok } 1 \\
\mathrm{X}_{2} & =\text { nilai rata-rata kelompok } 2 \\
\mathrm{~S}^{2}{ }_{1} & =\text { nilai varian terbesar }
\end{array}
$$


$\mathrm{S}^{2}{ }_{2} \quad=$ nilai varian terkecil

$\mathrm{n}_{1} \quad=$ jumlah sampel kelompok 1

$\mathrm{n}_{2} \quad=$ jumlah sampel kelompok 2

Kaidah keputusan :

Jika $\mathrm{t}$ hitung $\geq \mathrm{t}$ table, maka terdapat perbedaan signifikan

( $\mathrm{H}_{\mathrm{o}}$ ditolak $\mathrm{H}_{\mathrm{a}}$ diterima).

$\mathrm{t}$ hitung $\leq \mathrm{t}$ table, maka tidak ada perbedaan signifikan

( $\mathrm{H}_{\mathrm{o}}$ diterima dan $\mathrm{H}_{\mathrm{a}}$ ditolak).
Bahan ajar flash book dikatakan efektivitas digunakan dalam pembelajaran, apabila taraf signifikan $<0,05$ (t-0,05). Rumusan hipotesisnya adalah sebagai berikut:

Ho : tidak ada perbedaan antara hasil belajar siswa yang menggunakan bahan ajar dan tidak menggunakan bahan ajar flash book.

$\mathrm{Ha}$ : ada perbedaan anatara hasil belajar siswa yang menggunakan bahan ajar dan tidak menggunakan bahan ajar flash book.

\section{PEMBAHASAN}

Pada bagian hasil dan pembahasan akan dibahas proses pengembangan bahan ajar flash book dan pengujian kelayakan seta efektivitas bahan ajar flash book yang dikembangkan dengan model 4-D.

Pengembangan bahan ajar flash book menggunakan model 4-D yang meliputi 4 tahap, yaitu: (1) tahap pendefinisian (define), dalam tahap ini akan dilakukan analisis awal yang bertujuan untuk mengetahui kebutuhan mendasar dari sebuah pembelajaran. Sebuah kebutuhan didapatkan dari hal-hal yang diamanatkan undang-undang. Hal-hal yang harus dilakukan adalah menganalisis tujuan pembelajaran menurut kurikulum, perangkat pembelajaran, dan tantangan masa depan., analisis siswa, analisis konsep, analisis tugas dan perumusan tujuan pembelajaran (2) Tahap perancangan (design) berdasarkan pada tahap pendefinisian dimaksudkan untuk mendapatkan format atau draf awal bahan ajar flash book yang dikembangkan. Materi yang dikembangkan menjadi bahan ajar flash book adalah subtema kerajaan Islam di Indonesia. Bahan ajar flash book harus memperhatikan tentang materi dari bahan ajar serta format digital dari bahan ajar flash book yang dikembangkan. Dari tahap perancangan ini akan menghasilkan draft 1 yang akan dinilai kelayakannya oleh validator ahli (3) tahap pengembangan (develop) berdasarkan revisi dari masukan validator ahli maka akan dilakukan perbaikan yang menghasilkan draft II yang akan diujicobakan pada kelas eksperimen (4) tahap penyebaran (dissemite) peneliti menyebarkan produk bahan ajar flash book pada SDN Medokan Ayu/270 Surabaya untuk membantu dalam menyampaikan materi pada tema sejarah peradaban Indonesia subtema kerajaan Islam di Indonesia. Selain itu peneliti juga berencana menyebarkan secara lebih luas bahan ajar flash book pada website kumpulbagi.id dengan akun richard17 agar bisa didownload dimanfaatkan dan digunakan oleh guru yang membutuhkan. 
Validasi dilakukan oleh dua validator ahli yaitu validator ahli materi yaitu Drs. Suprayitno M.Si dan validator ahli media yaitu Dr. Bachtiar S Bachri, M.Pd. Dari penilaian kelayakan dari kedua validator tersebut diperoleh data sebagai berikut:

Tabel 2. Hasil Validasi

\begin{tabular}{|l|l|l|l|}
\hline No & $\begin{array}{l}\text { Validator } \\
\text { Ahli }\end{array}$ & Nilai & Kategori \\
\hline 1. & $\begin{array}{l}\text { Validator } \\
\text { Ahli Materi }\end{array}$ & $93,75 \%$ & $\begin{array}{l}\text { Sangat } \\
\text { baik }\end{array}$ \\
\hline 2. & $\begin{array}{l}\text { Validator } \\
\text { Ahli Media }\end{array}$ & $91,67 \%$ & $\begin{array}{l}\text { Sangat } \\
\text { baik }\end{array}$ \\
\hline
\end{tabular}

Berdasarkan hasil penilaian dari validator ahli tersebut diperoleh nilai $93,75 \%$ dari penilain validator ahli materi dengan kategori sangat baik, dan nilai $91,67 \%$ dari penilain validator ahli media dengan kategori sangat baik. Dengan demikian dapat disimpulkan bahwa bahan ajar flash book dengan kategori valid dan layak digunakan.

Kegiatan pengamatan aktivitas siswa dilakukan oleh peneliti yang bertindak sebagai pengamat yang mengikuti kegiatan pembelajaran dari awal hingga akhir. Pengamat mengamati kegiatan atau aktivitas siswa pada saat pembelajaran berlangsung. Pengamata dilakukan dalam tiga kali pertemuan di kelas $\mathrm{V}$ B. Berdasarkan hasil pengamatan tersebut, aktivitas siswa pada saat pembelajaran subtema kerajaan Islam di Indonesia dengan menggunakan bahan ajar flash book dikategorikan sangat baik, dengan rata-rata $85 \%$. Dengan demikian dapat disimpulkan bahwa aktivitas siswa dalam pembelajran berjalan sangat baik, siswa mampu berperan aktif dalam pembelajaran.

Kegiatan pengamatan aktivitas Guru dilakukan oleh peneliti yang bertindak sebagai pengamat yang mengikuti kegiatan pembelajaran dari awal hingga akhir. Pengamat mengamati kegiatan atau aktivitas peserta didik pada saat pembelajaran berlangsung. Pengamatan dilakukan dalam tiga kali pertemuan di kelas $\vee \mathrm{B}$. Berdasarkan hasil analisis pengamatan aktivitas guru pada saat pembelajaran subtema kerajaan Islam di Indonesia engan menggunakan bahan ajar flash book dapat dikategorikan baik, dengan rata-rata $83,89 \%$. Dengan demikian dapat disimpulkan bahwa aktivitas guru dalam pembelajaran berjalan baik, guru mampu berperan aktif dalam pembelajaran.

Analisis data penelitian bertujuan untuk membuktikan kebenaran dari pernyataan yang telah ditetapkan dalam hipotesis . Data akan dianalisis dengan Uji t, dengan data yang akan dianalisis adalah nilai hasil pre test dan post test kelas eksperimen dan kelas kontrol

Sebelum dilakukan uji $t$ terlebih dahulu dilakukan uji normalitas dan homogenitas data. Uji normalitas data dilakukan dengan menggunakan SPSS yakni uji Shapiro-Wilk, dan uji homogenitas data menggunakan uji Levene.

Berikut data hasil pengujian normalitas dan homogenitas data.

Tabel 3. Uji Normalitas Kelas Kontrol dan Kelas Eksperimen

\begin{tabular}{|l|l|l|}
\hline Kelas & Variabel & $\begin{array}{l}\text { Shapiro } \\
\text { Wilk (sig) }\end{array}$ \\
\hline \multirow{4}{*}{ Kelas Kontrol } & $\begin{array}{l}\text { Hasil } \\
\text { Belajar Pre } \\
\text { Test }\end{array}$ & .139 \\
\cline { 2 - 3 } & $\begin{array}{l}\text { Hasil } \\
\text { Belajar } \\
\text { Post Test }\end{array}$ & .069 \\
\hline $\begin{array}{l}\text { Kelas } \\
\text { Eksperimen }\end{array}$ & $\begin{array}{l}\text { Hasil } \\
\text { Belajar Pre } \\
\text { Test }\end{array}$ & .219 \\
\hline
\end{tabular}




\begin{tabular}{|l|l|l|}
\hline & Hasil & \\
& Belajar & .150 \\
& Post Test & \\
\hline
\end{tabular}

Tabel tersebut menunjukkan bahwa asumsi normalitas sudah terpenuhi terlihat dari taraf signifikan ShapiroWilk pada kelas kontrol 0,139 > 0,05 dan kelas eksperimen dengan taraf signifikan 0,219>0,05, maka dapat disimpulkan persebaran data nilai pre test kelas kontrol dan kelas eksperimen berdistribusi normal. Serta asumsi normalitas pada post test sudah terpenuhi terlihat dari taraf signifikan Shapiro-Wilk pada kelas kontrol $0,069>0,05$ dan kelas eksperimen dengan taraf signifikan $0,15>0,05$, maka dapat disimpulkan persebaran data nilai post test kelas kontrol dan kelas eksperimen berdistribusi normal.

Pengujian yang kedua adalah uji homogenitas data dengan menggunakan uji Levine. Data yang diperoleh dari kelas kontrol dan kelas eksperimen adalah sebagai berikut:

Tabel 4. Uji Homogenitas Kelas Kontrol dan Kelas Eksperimen

\begin{tabular}{|l|l|}
\hline Variabel & (sig) \\
\hline Pre Test & .126 \\
\hline Post Test & .968 \\
\hline
\end{tabular}

Berdasarkan tabel di atas tampak nilai signifikan pada pre test $0,126>0,05$ yang berarti $\mathrm{Ho}$ diterima dan $\mathrm{H}_{1}$ ditolak yang artinya varians kedua sampel (kelas) adalah homogen. Serta nilai signifikansi pada post test $0,968>0,05$ yang berarti Ho diterima dan $\mathrm{H}_{1}$ ditolak yang artinya varians kedua sampel (kelas) adalah homogen.

Setelah dilakukan uji prasyarat analisis data yaitu uji normalitas dan uji homogenitas, untuk menjawab hipotesis yang diajukan maka uji analisis yang dipergunakan dalam penelitian ini adalah independent sample t-test yang bertujuan untuk membandingkan rata-rata dari dua grup yang tidak berhubungan satu dengan yang lain dan kedua grup (kelas kontrol dan kelas eksperimen) tersebut mempunyai rata-rata yang sama atau tidak secara signifikan. Dasar pengujian hipotesis adalah thitung $>$ tabel maka $\mathrm{Ho}$ ditolak dan $\mathrm{Ha}$ diterima.

Nilai mean hasil belajar siswa (post test) dengan menggunaan bahan ajar flash book lebih tinggi dibandingkan dengan hasil belajar siswa tanpa menggunakan bahan ajar flash book. Dapat dilihat dari nilai mean hasil belajar siswa dengan menggunakan bahan ajar flash book pada kelas eksperimen sebesar 80, sedangkan siswa yang belajar tanpa menggunaan bahan ajar flash book pada kelas kontrol sebesar 71.38.

Berdasarkan nilai thitung hasil belajar siswa sebesar 3.979 (df. 54). Dari hasil analisis dengan uji Independent Sample T-test tersebut diperoleh nilai thitung (3.979) > ttabel (1.673) pada df.54 dan nilai signifikansi Sig. (2-tailed) tersebut lebih kecil dari nilai $\alpha(0,000<$ $0,05)$ maka hipotesis nihil $(\mathrm{Ho})$ yang diajukan ditolak dan hipotesis alternatif $(\mathrm{Ha})$ diterima. Berdasarkan hasil diatas, maka telah terbukti bahwa rata-rata hasil belajar siswa pada kelas eksperimen lebih baik secara signifikan dari pada rata-rata hasil belajar kelas kontrol. Hal ini menunjukkan bahwa hasil belajar siswa yang mengikuti pembelajaran dengan menggunakan bahan ajar flash book lebih baik daripada hasil belajar siswa yang mengikuti 
pembelajaran tanpa bahan ajar flash book. Jadi dapat disimpulkan bahwa "penggunaan bahan ajar flash book sejarah peradaban Indonesia berpengaruh terhadap hasil belajar siswa kelas $\mathrm{V}$ sekolah dasar".

Mengulas hasil penelitian yang diperolehnya dengan menggunakan pandangan orisinal peneliti dalam kerangka teori dan kajian empirik yang terdahulu. Hasil penelitian menyertakan tabel dan grafik secara ringkas dan menyatakan simpulan.

Apabila terdapat gambar dan tabel yang sangat besar, maka boleh untuk tidak dimasukan ke kolom dan untuk judul gambar atau grafik berada di bawah gambar atau grafik sedangnkan untuk judul tabel berada di atas tabel. Judul grafik dan tabel di tulis dengan 1 spasi.

\section{SIMPULAN}

Berdasarkan pada data penelitian dan diskusi data penelitian sesuai dengan rumusan masalah dari penelitian pengembangan bahan ajar flash book, maka dapat disimpulan bahwa bahan ajar flash book layak digunakan dalam pembelajaran di kelas. Hal ini dapat dilihat dari penilaian validator ahli materi yang memberikan penilaian dengan presentase $93,75 \%$ dengan kategori sangat baik dan validator ahli media yang memberikan penilaian dengan presentase $91,67 \%$ dengan kategori sangat baik.

Bahan ajar flash book berpengaruh dan efektif dalam meningkatkan hasil belajar siswa kelas $\mathrm{V}$ sekolah dasar. Terbukti dengan hasil analisis yang menunjukkan thitung (3.979) > tabel (1.673) pada df.54 dan nilai signifikansi Sig. (2-tailed) tersebut lebih kecil dari nilai $\alpha(0,000<0,05)$. Dengan nilai mean hasil belajar siswa dengan menggunakan bahan ajar flash book pada kelas eksperimen sebesar 80 , sedangkan siswa yang belajar tanpa menggunaan bahan ajar flash book pada kelas kontrol sebesar 71.38. Dapat diartikan bahwa rata-rata hasil belajar siswa pada kelas eksperimen lebih baik secara signifikan dari pada rata-rata hasil belajar kelas kontrol.

Berdasarkan hasil belajar siswa yang telah dicapai dengan penggunaan bahan ajar flash book, maka bahan ajar flash book ini dapat dijadikan sebagai salah satu alternatif sebagai sebagai sumber belajar siswa maupun bahan ajar dalam pembelajaran untuk dapat meningkatkan hasil belajar siswa sehingga akan terwujud sebuah pembelajaran yang aktif, efektif dan menyenangkan.

Menyajikan pembahasan hasil penelitian atau gagasan ilmiah, implikasi serta rekomendasi lebih jauh yang menjadi prospek kajian berikutnya. 


\section{DAFTAR PUSTAKA}

Clark, J and Paivo, A.(1991). Dual coding theory and education. Educational psychology review, 3 (3) page 149210

Muslich, Masnur.(2010). Text Book Writing. Yogyakarta: AR-RUZZ MEDIA.

Prastowo, Andi. (2014). Pengembangan Bahan Ajar Tematik:Tinjauan Teoritis dan praktik. Jakarta: PT Kencana.

Riduwan. 2011. Skala Pengukuran Variabel-Variabel Penelitian. Bandung: CV. Alfabeta.

Slameto.(2010).Belajar \& Faktor - Faktor yang Mempengaruhinya. Jakarta: PT. Rineka Cipta.

Sugiyono.(2011). Metode Penelitian Pendidikan. Bandung: CV Alfabeta
Tanner, M. Julee.(2014). Digital vs. Print: Reading Comprehension and the Future of the Book. San Jose State University, Vol 4.

Winarsunu, Tulus. 2009. Statistik dalam Penelitian Psikologi dan Pendidikan. Malang: UMM

Yau, Chris, HJ Lee \& Chris Messom. (2013). Can An Electronic Textbooks Be Part Of K-12 Education?:Challenges, Technological Solutions And Open Issues. The Turkish Online Journal of Educational Technology, Volume 12.

Yudhiantoro, Dhani.(2003). Panduan

Lengkap Menggunakan

Macromedia Flash. Yogyakarta: Penerbit Andi. 